\title{
Frequency, severity and causes of unexpected allergic reactions to food, a systematic literature review
}

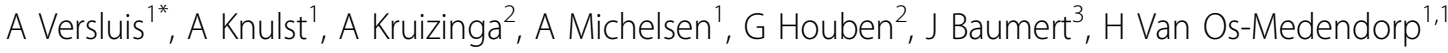 \\ From Food Allergy and Anaphylaxis Meeting (FAAM 2013) \\ Nice, France. 7-9 February 2013
}

\section{Background}

Food allergic patients have to deal with their diet. However, confusing labelling terms of precautionary labels can result in risk-taking behaviour. Even those patients that strictly adhere to their diet experience mild but also severe unexpected allergic reactions to food during their life. The aim was of this study was to describe the frequency, severity and causes of unexpected allergic reactions to food in food allergic patients, aged $>12$ years, in order to improve health care for these patients.

\section{Methods}

A systematic review was carried out. A search was performed by two researchers, in six electronic databases (CINAHL, Cochrane, EMBASE, Medline, Psychinfo and Scopus). The search was performed with keywords relating to the frequency, severity and causes of unexpected allergic reactions to food.

\section{Results}

Eighteen studies met de inclusion criteria; thirteen observational and five qualitative studies. Little is known about the frequency of unexpected reactions. Peanut, tree nuts and milk are the main causal foods. Severe reactions and even fatalities occur, but prevalence data are scarce. Most reactions take place at home, but a significant number also take place when eating at friends or in restaurants. Labelling issues, but also attitude and risky behaviour of patients can attribute to unexpected reactions.

\section{Conclusion}

Prospective studies are needed to get more insight in the prevalence, severity, quantity of unintended allergen

${ }^{1}$ Dermatology \& Allergology, UMC Utrecht, Utrecht, the Netherlands

Full list of author information is available at the end of the article ingested and causes of unexpected allergic reactions to food, to be able to optimize strategies to support patients in dealing with their food allergy.

\section{Disclosure of interest}

None declared.

\section{Author details}

'Dermatology \& Allergology, UMC Utrecht, Utrecht, the Netherlands. ${ }^{2} T N O$, Zeist, the Netherlands. ${ }^{3}$ Food Science and Technology Department, University of Nebraska-Lincoln, Lincoln, NE, USA.

Published: 25 July 2013

doi:10.1186/2045-7022-3-S3-P134

Cite this article as: Versluis et al:: Frequency, severity and causes of unexpected allergic reactions to food, a systematic literature review. Clinical and Translational Allergy 2013 3(Suppl 3):P134.

\section{Submit your next manuscript to BioMed Central and take full advantage of: \\ - Convenient online submission \\ - Thorough peer review \\ - No space constraints or color figure charges \\ - Immediate publication on acceptance \\ - Inclusion in PubMed, CAS, Scopus and Google Scholar \\ - Research which is freely available for redistribution \\ Submit your manuscript at www.biomedcentral.com/submit}

